C. V. B. Marquand or with F. Ballard), J. M. Cowan (thirteen species), A. B. Rendle (five species), and others including J. Anthony, G. Taylor, W. B. Turrill and T. A. Sprague. The volume is edited by Dr. J. Ramsbottom and does credit to editor and contributors. The price may appear to be high, but the illustrations alone make it good value and a real acquisition to any botanical library.

\section{Biological Effects of Ultra-Sound Waves}

A sectron of Messrs. Hermann's "Actualités Scientifiques et Industrielles" series of publications is being devoted to investigations of the effects of radiation on living organisms; it is under the charge of Prof. N. Marinesco, director of research in the Institute of Physico-chemical Biology, Paris. Two parts dealing with ultra-sound waves and their properties have already appeared: (1) "Proprietes piézo-chimiques, physiques et biophysiques des Ultrasons. Technique des ondes élastique de haute frequence", and (2) "Propriétés des Ultra-sons. Destruction des micro-organismes. Preparation des colloides a basses temperatures. Réactions explosives. Reactions photochimiques". Both are written by Prof. Marinesco. The first 56 pages and 5 plates (15 francs) describes the electro-elastic properties of quartz, the production of stationary waves in liquids, the intensity of the radiation, the pressure it exerts and the absorption it undergoes. The second, of 68 pages and 7 plates (18 francs), describes the effects of ultra-sound waves in sterilizing water and milk, in producing emulsions, in detonating explosives and in accelerating chemical reactions with special reference to those in photography. Many of the plates are reproductions of photographs taken by the author. Bibliographies are provided.

\section{International Union against Cancer}

The Third International Cancer Congress under the auspices of the International Union against Cancer will be held in Atlantic City, New Jersey, on September 11-16, 1939. The president of the Congress is Prof. Francis Carter Wood, director of the Institute of Cancer Research of Columbia University ; Dr. Donald S. Childs of Syracuse, New York, is the secretary-treasurer; and Dr. A. L. Loomis Bell of Long Island College Hospital, Brooklyn, New York, is in charge of transportation and exhibits. The proposed sections are as follows: general research; biophysics; genetics; general pathology of cancer ; surgery of cancer; radiological diagnosis of cancer ; radiotherapy of cancer; statistics; and education. Details concerning section chairmen, committees and other data will be announced later. Further information can be obtained from the Institute of Cancer Research, 1145 Amsterdam Avenue, New York, N.Y.

\section{A Regional Survey Field Service Pocket-book}

ThE Le Play Society's well-known "Discovery" chart has been revised and enlarged and its subject. matter has been put into pocket-book form with blank leaves for maps and notes. In this form it is published under the title "Exploration" at 4d., postage $\mathrm{l} d$. It directs attention to some hundreds of possible fields of local exploration grouped under the major headings: geology, rivers and water-supply, weather and climate, vegetation and open spaces, agriculture, zoology, archæology, history, communications, occupations, folk-lore, place-names, modern and changing conditions, camping and rambling. It is calculated to stimulate youthful zest for exploration and arouse and develop scientific curiosity. An ethical aim is provided by the following passage, appearing on the front page, reminiscent of the teaching of Patrick Geddes and Victor Branford: "If you learn to know your own place well, and in so doing learn to love it more, it will help you to understand and appreciate other places, and to sympathise with their problems". It should prove serviceable to scoutmasters and girl-guides as well as to others engaged in the teaching of local history, local geography and civics and in training for eitizenship.

\section{Colonial Service Appointments}

THE following appointments and promotions have recently been made in the Colonial Service : $R$. O. Roberts, field geologist, Uganda; W. L. Stapleton, inspector of mines, Malaya ; F. G. Bridges, inspector of plants and produce, Nigeria; M. J. Douglass, agricultural officer, Sierra Leone; J. Ford, entomologist, Tsetse Research Department, Tanganyika Territory ; K. S. Hocking, secretary, Tsetse Research Department, Tanganyika Territory; A. R. Jones, meteorological assistant, Sierra Leone; A. G. Robertson, field officer, Tsetse Research Department, Tanganyika Territory; F. L. Vanderplank, field officer, Tsetse Research Department, Tanganvika Territory; E. F. Whiteside, field assistant, Tsetse Research Department, Tanganyika Territory ; T. W. Brown (agricultural officer), botanist, Research Branch, Department of Agriculture, Malaya; B. G. A. Low (botanist, Research Branch, Department of Agriculture), agricultural officer, Field Branch, Malaya; F. B. Higgins (senior inspector of mines, Nigeria), senior inspector of mines, Gold Coast; H. H. Cobon (assistant superintendent of surveys), superintendent of surveys, Malaya; F. W. Abbott (laboratory assistant, Medical Department), laboratory assistant, Grade I, Medical Department, Gold Coast ; P. A. Clearkin (formerly deputy director of Laboratory Service, Tanganyika Territory), bacteriologist and pathologist, British Guiana (temporary appointment) ; C. K. Robinson (agricultural assistant), agricultural superintendent, Saint Vincent; G. C. Stevenson (assistant botanist, British West Indies Central Sugar Cane Breeding Station, Barbados), botanist, Sugar Cane Research Station, Mauritius.

\section{Shower of Bright Meteors}

A REMARKABLE shower of fireballs is reported to have been seen in southern Sweden on May 27 between $18^{\mathrm{h}} 20^{\mathrm{m}}$ and $20^{\mathrm{h}} 12^{\mathrm{m}}$ U.T. About $18^{\mathrm{h}} 40^{\mathrm{m}}$, two specially bright fireballs, visible in full sunshine, appeared over Bornholm Island. The general direction was from west to east. Further details of these and other fireballs are requested by $\mathrm{A}$. Corlin, 